\title{
The Influence of PQ4R Strategy and Mathematical Reasoning Ability Towards Mathematical Communication Skills
}

\author{
Alberta Parinters Makur * \\ Department of Mathematics Education, STKIP Santu Paulus, Ruteng-NTT, Indonesia \\ *Corresponding Author, alberta.makur@stkipsantupaulus.ac.id
}

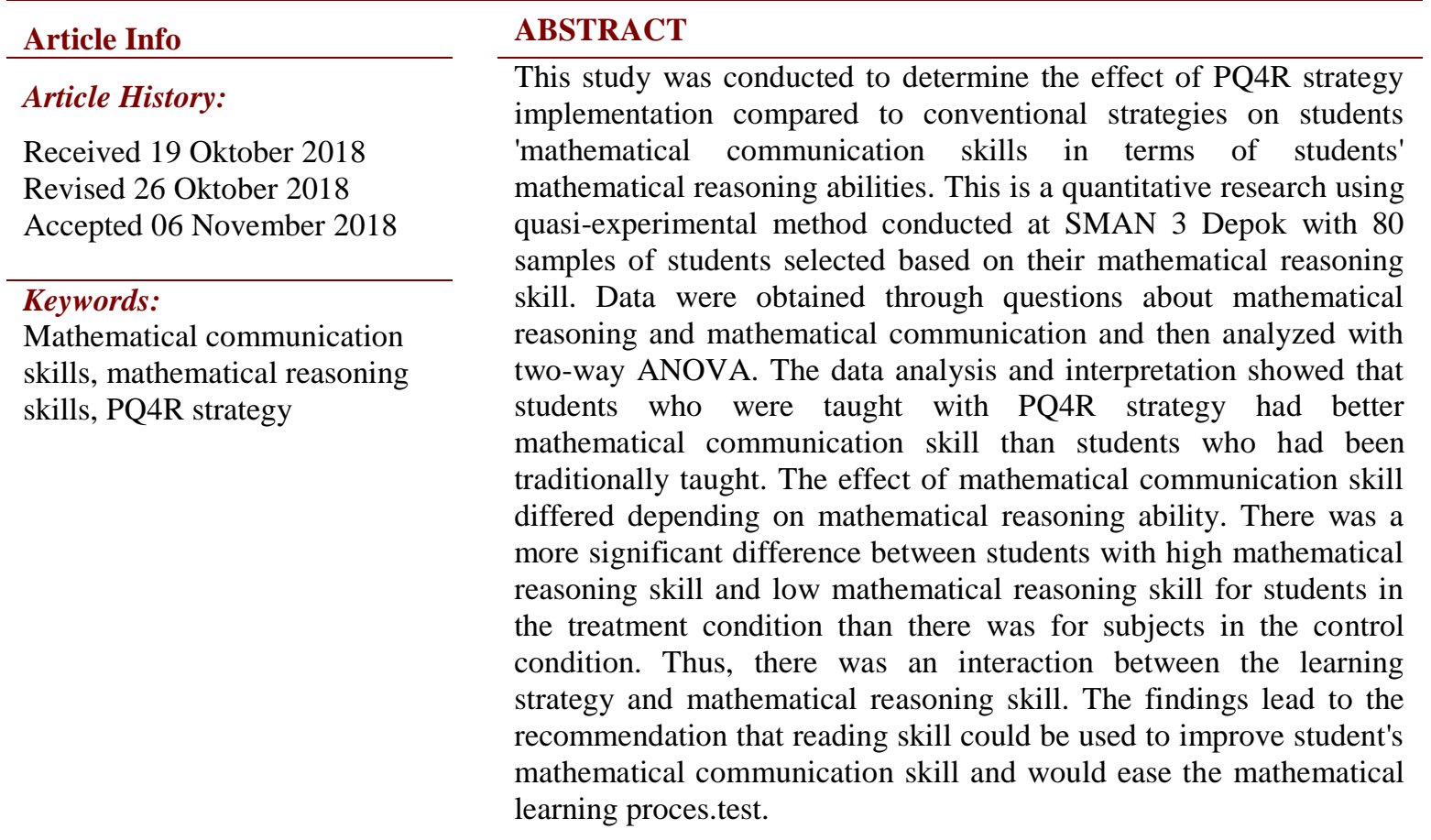

Copyright (C) 2019 by the authors; licensee Department of Mathematics Education, University of Singaperbangsa Karawang. All rights reserved.

This is an open access article distributed under the terms of the CC BY-SA license. (http://creativecommons.org/licenses/by-sa/4.0)

\section{INTRODUCTION}

Education is a significant milestone for achieving a good quality of human resources. Many researchers emphasize to be successful in the $21^{\text {st }}$ century, students must be critical thinkers, problem solvers, collaborators, information and technology literate, flexible and adaptable, innovative and creative, communicators effective, and initiator (Brenner, 1998; Forrest, 2008; Ghasempour, Kashefi, Bakar, \& Miri, 2012; Miner, 2005; Wichelt, 2009). Furthermore, mathematics as part of the school curriculum is directed to support the achievement of the educational goals. Mathematics learning should be led to the development of students' processes and thinking skills. The contribution of mathematics learning will be achieved if (1) Mathematics is seen not merely arithmetic; (2) Mathematics is a problem posing, and problem-solving; (3) Mathematics is the study of patterns and relationships; (4) Mathematics is a language; (5) Mathematics is a way, and a tool of thought; (6) Mathematics is a science that develops dynamically; (7) Math is activity (Suryadi, 2010).

Mathematical material and mathematical reasoning are two interrelated matters 
because the mathematical content is understood through mathematical reasoning and mathematical reasoning trained through learning mathematics (Baig \& Halai, 2006; Foster \& Cresap, 2012; Kaur, 2012; Larson, Whitin, \& Alexander, 2010; Rasmussen \& Marrongelle, 2006; Rubinstein-Avila \& Mcgraw, n.d.; Stebila, 2008; Vukovic, Roberts, \& Green Wright, 2013). By studying mathematics, students' thinking skills will increase as the mathematical thinking patterns require and involve critical, systematic, logical, and creative thinking so that students will be able to conclude from facts or data they get or know quickly (Baig \& Halai, 2006). As students are given the opportunity to work in groups collecting and presenting data, they show good progress as they listen to the ideas of other students, discuss them together and then draw conclusions (Larson et al., 2010). Good reasoning abilities in students facilitate the occurrence of information comprehension, information delivery, and information exchange from information sources. That is, there is a link between the strength of reasoning with the ability to communicate.

Communication plays a central role in the learning and teaching process (Forrest, 2008; Hirschfeld-cotton, 2008; Rubinstein-Avila \& Mcgraw, n.d.; Wichelt, 2009). It was explained that communication occurs between students and between students with teachers. Communication has a stable relationship with other mathematical processes where communication is required to complement every different mathematical process. For mathematical reasoning and mathematical communication of students to develop well, then in the process of learning mathematics, teachers need to provide opportunities for students to be able to improve their ability in communicating mathematical ideas.

There are two reasons why mathematical communication is so essential (Lim \& Chew, 2007). First, math is a language. Mathematics is not only a tool of thought that helps to find patterns, solve problems and make conclusions but also a device to communicate thoughts, ideas clearly, precisely and concisely. In fact, mathematics is considered a universal language that has unique and structured symbols. Everyone in the world can use the language to communicate mathematical information (scientific information) even though there are differences in native languages. Second, mathematics learning is a social activity involving at least two parties, teachers and students. Thoughts and ideas are critical to being communicated to others through language during the learning process. The exchange of ideas and experiences is a process of teaching and learning. By encouraging students to talk about their ideas is the best way to find gaps, inconsistencies, or incomprehension in their thinking.

The student's active role in learning is seen in the learning process in the classroom to achieve an active knowledge construction. NCTM (2000) states when students are challenged to think and reason about mathematics and communicate their thoughts to others either orally or in writing, they have learned to clarify and reassure their understanding. Listening to other people's explanations also gives students the opportunity to build their knowledge. Conversations that explore mathematical ideas from different perspectives help those who participate in the discussion to sharpen their thinking and can make relevant relationships (Lu, 2008; Lagur, Makur, \& Ramda, 2018).

It was required to use strategies in the learning process that can improve students' communication skills. The strategy chosen should be tailored to the characteristics of students in today's modern era. Students in Indonesia today can be categorized into Y generation. The behaviour or characteristics of generation $\mathrm{Y}$ in each region of Indonesia are different, depending on where he/she grew up, the economic and social strata of his family (Ho, 2010). But overall, it can be seen that the pattern of communication is more open than previous generations. This generation is a fanatic social media user, and his life 
is heavily influenced by technological developments. This is the generation that in the birth was already dealing with Google, Facebook, and Twitter. The world of education needs to take advantage of this situation carefully where students can now get knowledge from various sources on the internet. The easy access to the internet has a significant effect on the reading and writing activities of each student who becomes higher. Utilization of information technology can be optimized by utilizing this situation where students prefer to read and then express their ideas through writing.

Reading and writing is an ideal medium for achieving the expected learning aspects from the government. When reading or writing, students try to understand new knowledge and integrate it with newly acquired knowledge while reading. This is of course in line with the characteristics of current students who fall into the Y generation category, where they actively read the source of information and then express it in writing. One strategy that can be used to improve reading skills is the PQ4R strategy (Preview, Question, Read, Reflect, Recite, and Review) developed by Thomas and Robinson in 1972. The PQ4R strategy allows students to build their knowledge through the active reading prpcess (Mayasari, 2011; Sriadi, 2012; Tandililing, 2011). This strategy is expected to support the achievement of five aspects of the curriculum set by the government. With this strategy, students are helped to remember the material they have read and can help the learning process in the classroom with the activities of reading a book of mathematics or other mathematics learning resources. The skills developed by implementing this strategy are the reading skills which can indeed be a bridge to mastering knowledge independently.

Based on the background of problems that have been presented, researchers see the need to improve students' mathematical communication skills. This needs to be done not only to optimize student learning outcomes in schools but also to support student life as part of the community. Reading habits are one of the ideal ways to achieve this goal. The ability of mathematical reasoning is necessary to understand the mathematical reading material. Therefore, the researcher will analyze the influence of PQ4R strategy implementation regarding mathematical reasoning ability to students' mathematical communication ability. Specifically, the following research questions were addressed: 1 . was there a difference in the capacity of mathematical communication between students given PQ4R strategy (Preview, Question, Read, Reflect, Recite, Review) in learning mathematics with students who in their learning using conventional strategy? 2. was there an interaction between learning strategy and mathematical reasoning ability to mathematical communication skills?

\section{METHOD}

This research was conducted using a quantitative research approach. The research design used in this research is design treatment by level $(2 \times 2)$. Independent variable is learning strategy and students 'mathematical reasoning ability (moderator variable), while the dependent variable is students' mathematical communication ability. With this design will be seen the effect of treatment (PQ4R strategy) on students 'mathematical communication abilities when viewed from the level of students' mathematical reasoning abilities. The matrix design can be seen in Table 1 . 
Table 1. Matrix design

\begin{tabular}{ccc}
\hline $\begin{array}{l}\text { Mathematical } \\
\text { reasoning ability } \\
\text { category }\end{array}$ & \multicolumn{2}{c}{ Learning strategies } \\
\cline { 2 - 3 } & PQ4R $\left(A_{1}\right)$ & Conventional $\left(A_{2}\right)$ \\
\hline High $\left(B_{1}\right)$ & $A_{1} B_{1}$ & $A_{2} B_{1}$ \\
\hline Low $\left(B_{2}\right)$ & $A_{1} B_{2}$ & $A_{2} B_{2}$ \\
\hline
\end{tabular}

This design is used to see the type of influence of treatment (PQ4R strategy) on students' mathematical communication ability. Three effects want to be seen are:

1. Main Effects $\left(A_{1}\right.$ and $\left.A_{2}\right)$ : Differences in communication skills of students treated (given PQ4R strategies) with conventional strategies.

2. Interaction Effects $\left(A_{i} \times B\right.$ and $\left.Y\right)$ : Interaction between learning strategy and mathematical reasoning ability to mathematical communication ability

\section{Research Procedure}

1. Determining State Senior High School 3 Depok by purposive to be a place of research implementation. This study was conducted with attention to the characteristics of the population include school quality, teacher qualifications, student characteristics and the curriculum used.

2. Identify all students of SMA Negeri 3 Depok and determine the reachable population is the students of grade XI SMA Negeri 3 Depok.

3. From 6 class XI IPA SMA Negeri 3 Depok 4 classes were chosen randomly, where two classes to be used as experiment class and 2 class to be control class. Before the observation class, a one-way ANOVA test was performed to ensure that the observation class was in an equivalent condition. The analytical requirements test for one-way ANOVA is the normality test and homogeneity test. Using the help of SPSS Statistics v17 it was seen that these classes came from normally distributed and homogeneous populations. Then with one path ANOVA test, it was found that each class of observation has the same condition statistically where the value $p=0.106$.

4. Furthermore, all students from both groups were given tests to determine the ability of mathematical reasoning. Then from the test results are analyzed to identify students who have high mathematical reasoning ability and have the low mathematical reasoning ability to math lessons. Of each class, $27 \%$ of the students were selected for the low mathematical reasoning group and $27 \%$ of the students for the high mathematical reasoning group. This is in line with Dragon (2013) which says that empirically $27 \%$ is suitable for large respondents and is considered the most optimal to make the extreme groups as large and possible as possible. Thus expected from two different groups have high reliability and contrast.

5. From the sampling result, the students were grouped into two groups as seen in Table 2 , i.e. students who have high mathematical reasoning ability and low mathematical reasoning ability both in the control group and experimental group. However, not every student is selected but instead randomly selected students who will enter as research subjects. Then from each group given the treatment and posttest, obtained results in 4 groups that will be seen the ability of mathematical communication that is: group $A_{1} B_{1}$, group $A_{2} B_{1}$, group $A_{1} B_{2}$, and group $A_{2} B_{2}$. 
Table 2. Number of Students Based Early Mathematical Ability

\begin{tabular}{lcc}
\hline Mathematical reasoning ability category & \multicolumn{2}{c}{ Learning strategies } \\
\cline { 2 - 3 } & PQ4R $\left(\boldsymbol{A}_{\mathbf{1}}\right)$ & Conventional $\left(\boldsymbol{A}_{\mathbf{2}}\right)$ \\
\hline High $\left(B_{1}\right)$ & 20 & 17 \\
\hline Low $\left(B_{2}\right)$ & 20 & 19 \\
\hline Total & 40 & 36 \\
\hline
\end{tabular}

6. The implementation of the treatment using the two learning strategies is divided into three namely 1 meeting for giving the instrument of mathematical reasoning ability in the experimental class and the class of dick to categorize the students into high mathematical reasoning ability and low mathematical reasoning ability, 6 meetings are used for the treatment that is PQ4R strategy in-class experiments and conventional strategies in the control class, and 1 meeting for the implementation of the final test that measures students' mathematical communication abilities in the experimental class and the dick class. The treatment design of each group can be seen in Table 3 .

Table 4. Treatment Design

Experiment Class (PQ4R strategy)

1. The teacher informs the student about the purpose of the lesson, reads the material and explains how to find the main idea (5 minutes)

2. Students quickly learned the instructional material as instructed by the teacher ( 5 minutes)

3. Students are asked to write questions related to learning materials on question cards (5 minutes)

4. Students read and answer questions on question cards that have been written before ( 25 minutes)

5. The teacher explains and discusses the learning materials in the book or LKS as well as discusses the students' answers regarding the questions that they (25 minutes)

6. Students complete questions related to teaching materials provided by teachers ( 20 minutes)

7. Teachers and students conclude the material that has been discussed ( 5 minutes)

\section{Control Class (Conventional}

Strategy)

1. The teacher explains the material (45 minutes)

2. Students complete questions related to learning materials. (30 minutes)

3. Teacher checks student answers and discusses the answers together. (15 minutes)

\section{RESULTS AND DISCUSSION}

\section{Results}

The results of the data analysis illustrate that: (1) the mean value of mathematical communication ability of the group of students using the PQ4R strategy (12.68) is higher than the average score of mathematical communication ability of the student group using conventional strategy (9.81); (2) the average score of mathematical communication ability of the group of students using the PQ4R strategy and having high mathematical reasoning ability (14.60) higher than the mathematical communication ability of the students group 
using conventional strategy and having high mathematical reasoning ability (9.53); (3) the average score of mathematical communication ability of the group of students using the PQ4R strategy and having low mathematical reasoning ability (10.75) is higher than the average score of mathematical communication ability of the student group using the conventional strategy and having low mathematical reasoning ability (10.05).

The result of deviation standard analysis illustrates that: (1) the standard deviation value of mathematical communication ability of group of students using PQ4R strategy (3.645) is higher than standard deviation value of mathematical communication ability of student group using conventional strategy (3.328), so that data of group mathematical communication ability students using conventional strategies are more homogeneous than the mathematical communication ability data of groups of students using the PQ4R strategy; (2) the standard deviation value of mathematical communication ability data of group of students using PQ4R strategy and having high mathematical reasoning ability $(2,891)$ lower than standard deviation value of mathematical communication ability of student group using conventional strategy and possess high mathematical reasoning ability $(3,676)$, so that the data of students 'mathematical communication ability using PQ4R strategy and having high mathematical reasoning ability is more homogeneous than the data of students' mathematical communication ability using conventional strategy and having high mathematical reasoning ability; (3) the standard deviation value of mathematical communication group data of students using PQ4R strategy and having low mathematical reasoning ability (3.354) higher than standard deviation value of mathematical communication group ability of students using conventional strategy and having low mathematical reasoning ability $(3,064)$, so that the data of students' mathematical communication ability using conventional strategy and having low mathematical reasoning ability is more homogeneous than the data of mathematical communication ability of student group using PQ4R strategy and having low mathematical reasoning ability.

Data on mathematical communication skills of groups of students using PQ4R strategies and those using conventional strategy related to high or low mathematical reasoning abilities are listed in Table 5.

Table 5. Descriptive Statistical Analysis of Math Communication Skill

\begin{tabular}{llll}
\hline Math Reasoning Category & & \multicolumn{2}{l}{ Learning Strategy } \\
\cline { 3 - 4 } & Statistics & PQ4R $\left(\boldsymbol{A}_{\mathbf{1}}\right)$ & Conventional $\left(\boldsymbol{A}_{\mathbf{2}}\right)$ \\
\hline \multirow{3}{*}{ High $\left(B_{1}\right)$} & $\mathrm{N}$ & 20 & 17 \\
& Mean & 14.60 & 9.53 \\
& Deviation Standard & 2.891 & 3.676 \\
Low $\left(B_{2}\right)$ & $\mathrm{N}$ & 20 & 19 \\
& Mean & 10.75 & 10.05 \\
\multirow{2}{*}{ Total } & Deviation Standard & 3.354 & 3.064 \\
& $\mathrm{~N}$ & 40 & 36 \\
& Mean & 12.68 & 9.81 \\
& Deviation Standard & 3.654 & 3.328 \\
\hline
\end{tabular}




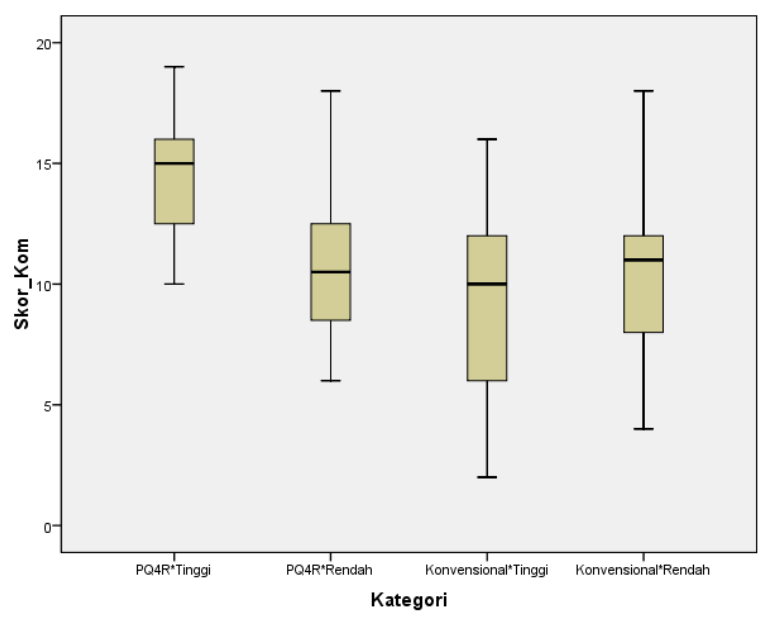

Figure 1. Boxplot students' math communication skills based on learning strategies and categories of math reasoning abilities

The hypothesis tested in this research is the influence of the main effect and the interaction effect. The impact of the main factors that is meant in this research is the difference of mathematical communication ability between groups of students using PQ4R strategy with the group of students using conventional strategy. While the influence of interaction interaction effect is the influence of interaction between learning strategies and the ability of mathematical reasoning to the ability of mathematical communication. If there is an interaction between learning strategy and mathematical reasoning ability to mathematical communication ability, then continued with simple effect test, that is: (1) test of difference of mathematical communication ability between student group using PQ4R strategy with student group using conventional strategy in student group have a high reasoning ability, and (2) test differences in mathematical communication skills between groups of students using PQ4R strategy with groups of students using conventional strategies in groups of students with low reasoning ability.

Hypothesis testing in this study using analysis of variance (ANOVA) two lines followed by Scheffe Test.

1. Differences in Mathematical Communication Skills between Student Groups Using PQ4R Strategies with Student Groups Using Conventional Strategies

The test of the null hypothesis examines whether there is a difference in mathematical communication skills between groups of students using PQ4R strategies with groups of students using conventional strategies. The hypothesis test is done by using the help of SPSS Statistics 17.0 that is by test Independent Sample t-test. Previously, the four data that appeared on the boxplot were eliminated. The SPSS output for the test of mathematical communication ability test results based on the learning strategy is obtained.

It has been shown before that the results of mathematical communication ability tests based on the variables of learning strategy have the same variant. SPSS output shows that value of Sig. $=0.525$. Based on the homogeneity test by using the F test, since the probability value is greater than $\alpha=0.05, H_{0}$ is accepted or the two population variances are the same (homogeneous).

Decision-making in t-Test analysis can be done by comparing the Sig probability value. 2-tailed with significance value $\alpha=0.05$. Based on Error! Reference source not found., the value of Sig significance is obtained. 2-tailed $p=0.001$. The level of significance used in this study is $\alpha=0.05$. Since the value of $p<\alpha$ then $H_{0}$ is rejected. So it can be concluded that there is a significant difference in the average of mathematical 
communication ability test result of a group of students using PQ4R strategy $\left(A_{1}\right)$ with the average of mathematical communication ability test result of student group using strategy $\left(A_{2}\right)$. That is, the mathematical communication ability between groups of students using the PQ4R strategy is higher than that of students using conventional strategies.

2. The interaction between learning strategy and mathematical reasoning ability to mathematical communication ability

The testing of the null hypothesis examines whether there is an interaction between learning strategies and mathematical reasoning abilities of mathematical communication skills. A hypothesis test is done by using SPSS Statistics 17.0 with General Linear Model Univariate. SPSS output for interaction testing is shown in Table. The results of the analysis can be seen in the lines of Strategy* Reasoning. The results of the analysis indicate the interaction between strategy and reasoning ( $p=0.005$ which resulted in the rejection of $H_{0}$ which states no interaction between strategy and reasoning). This means that there is an interaction between learning strategies with the ability of mathematical reasoning to the ability of mathematical communication.

Table 5. Interaction Testing Results

\begin{tabular}{|c|c|c|c|c|c|}
\hline Source & $\begin{array}{l}\text { Type III Sum of } \\
\text { Squares }\end{array}$ & df & $\begin{array}{l}\text { Mean } \\
\text { Square }\end{array}$ & $\mathbf{F}$ & Sig \\
\hline Corrected Model & 306.688 & 3 & 102.229 & 9.741 & .000 \\
\hline Intercept & 9547.599 & 1 & 9547.599 & 907.216 & .000 \\
\hline Reasoning & 52.340 & 1 & 52.340 & 4.973 & .029 \\
\hline Strategy & 157.335 & 1 & 157.335 & 14.950 & .000 \\
\hline Reasoning*Strategy & 90.445 & 1 & 90.445 & 8.594 & .005 \\
\hline Error & 757.733 & 72 & 10.524 & & \\
\hline Total & 10796.000 & 76 & & & \\
\hline Corrected Total & 1064.421 & 75 & & & \\
\hline
\end{tabular}

The form of interaction between learning strategies and mathematical reasoning abilities is shown in Figure 2.

Estimated Marginal Means of Skor_Kom

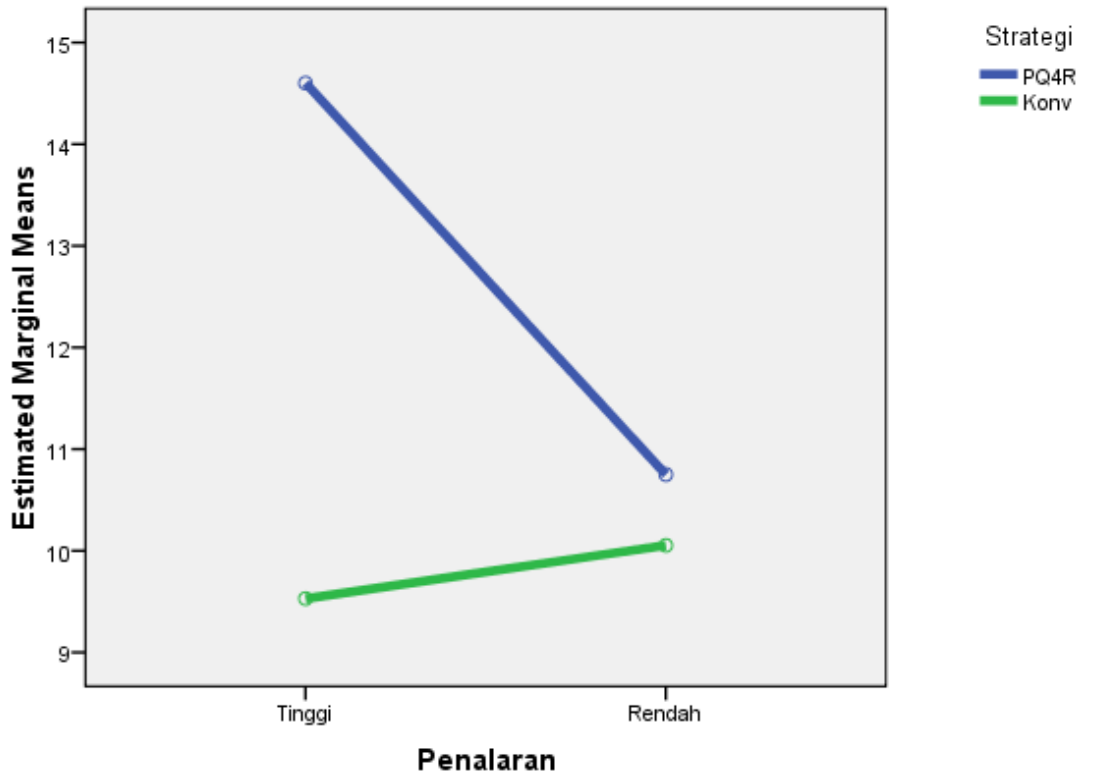

Figure 2. Interaction learning strategies and math reasoning abilities 
Figure 2 above shows the average mathematical communication ability of groups of students using PQ4R strategies that have high mathematical reasoning abilities $\left(A_{1} B_{1}\right)$ higher than the average of students' mathematics learning outcomes using conventional strategies that have high mathematical reasoning ability $A_{2} B_{1}$ ) and the mean mathematics learning outcomes of groups of students using PQ4R strategies that have low mathematical reasoning abilities $\left(A_{1} B_{2}\right)$ are higher than average student learning outcomes using conventional strategies that have low mathematical reasoning abilities $\left(A_{2} B_{2}\right)$.

The slope of the two lines above shows that there is an interaction between two independent variables to the dependent variable. In other words, the interaction can be interpreted that the effect of learning strategy on the ability of mathematical communication depends on students' mathematical reasoning abilities. Because of the interaction, the treatment effect can not be read directly. A follow-up or post hoc test (using the Scheffe test) is required to see the treatment effect. The SPSS output for this test result is shown in Table 6 below.

Table 6. Test of Between-Subject Effects

\begin{tabular}{lllllll}
\hline Source & $\begin{array}{l}\text { Type } \\
\text { Sum }\end{array}$ & $\begin{array}{c}\text { III } \\
\text { Squares }\end{array}$ & df & Mean Square & F & Sig \\
\hline Corrected & 306.688 & 3 & 102.229 & 9.741 & .000 \\
Model & & & & & \\
Intercept & 9547.599 & 1 & 9547.599 & 907.216 & .000 \\
Category & 306.688 & 3 & 102.229 & 9.741 & .000 \\
Error & 757.733 & 72 & 10.524 & & \\
Total & 10796.000 & 76 & & & \\
Corrected Total & 1064.421 & 75 & & & \\
\hline
\end{tabular}

Table 6 shows that the four combinations (PQ4R strategies * high reasoning, PQ4R strategies * low reasoning, conventional strategies * high reasoning, conventional strategies * low reasoning) in the category variables show significant values $(\mathrm{p}=0.000)$. Because of the significance, it can be continued by looking into the multiple comparisons or post hoc sections. If the analysis of the high variance is known only that there is a difference in mathematical communication ability concerning the combination of learning strategy and mathematical reasoning ability just, then the post hoc can be viewed in detail as in the following.

Table 7. Post Hoc Test

\begin{tabular}{|c|c|c|c|c|c|c|}
\hline \multirow{3}{*}{$\begin{array}{l}\text { (I) } \\
\text { Category }\end{array}$} & \multirow{3}{*}{$\begin{array}{l}\text { (I) } \\
\text { Category }\end{array}$} & \multirow{3}{*}{$\begin{array}{l}\text { Mean Difference } \\
\text { (I-J) }\end{array}$} & \multirow{3}{*}{$\begin{array}{l}\text { Std. } \\
\text { Error }\end{array}$} & \multirow{3}{*}{ Sig. } & \multirow{2}{*}{$\begin{array}{l}95 \% \\
\text { Interval }\end{array}$} & \multirow[t]{2}{*}{ Confidence } \\
\hline & & & & & & \\
\hline & & & & & Lower & Upper \\
\hline \multirow[t]{3}{*}{ E1 } & E3 & 3.85 & 1.026 & .005 & 0.91 & 6.79 \\
\hline & K1 & 5.07 & 1.070 & .000 & 2.01 & 8.13 \\
\hline & K3 & 4.55 & 1.039 & .001 & 1.57 & 7.52 \\
\hline \multirow[t]{3}{*}{ E2 } & E1 & -3.85 & 1.026 & .005 & -6.79 & -0.91 \\
\hline & $\mathrm{K} 1$ & 1.22 & 1.070 & .730 & -1.84 & 4.28 \\
\hline & K2 & 0.70 & 1.039 & .929 & -2.28 & 3.67 \\
\hline
\end{tabular}


Based on Table 7, it can be seen that:

a. Since $\operatorname{Sig}=0.000$ for category $E_{1}$ and $K_{1}$, it can be concluded that there is a significant difference in mathematical communication ability between the application of PQ4R strategy to students with high reasoning ability $\left(E_{1}\right)$ and conventional strategy in students with high reasoning ability $\left(K_{1}\right)$.

b. Since $\operatorname{Sig}=0.929$ for category $E_{3}$ and $K_{3}$, it can be concluded that there is no significant difference in mathematical communication ability between the application of PQ4R strategy to students with low reasoning ability $\left(E_{3}\right)$ and conventional strategy in students with low reasoning ability $\left(K_{3}\right)$.

\section{Discussion}

The general purpose of this study is to obtain a complete picture of the effect of PQ4R learning strategy treatment and mathematical reasoning ability on mathematical communication ability for high school students. This treatment for six times the meeting is applied in SMAN 3 Depok.

The results of hypothesis testing based on two-way analysis of variance (ANOVA) found that there are differences in mathematical communication ability of students group using PQ4R learning strategy with mathematical communication ability of student group using conventional learning strategy. This test indicates that the mathematical communication ability of the group of students using the PQ4R strategy is higher than the mathematical communication ability of the group of students using the conventional strategy.

This fact can be explained by several reasons, that the PQ4R strategy emphasizes student-centered activities. Glynn \& Muth (1994) argue that good learning situations are reflected in activities where students construct their concepts of new knowledge linkages with previously known knowledge. Students must learn the concept as a network of related information, not as a collection of facts. Learning situation like this is also reflected by the activity of reading and writing scientific texts. Reading and writing is an ideal medium for building conceptual relationships of knowledge. When reading or writing, students try to understand new knowledge and integrate it with newly acquired knowledge while reading.

Conventional strategies show the dominance of teachers in the classroom where students are generally passive only. The teacher provides enough material and instantly gives examples of problems on the board. The information the students get will be confined to what the teacher says. The absence of the proposed problem tends to shut down the students' ability to communicate.

The results of this study are synergistic with Tandililing (2011) which states that the use of Preview, Question, Read, Reflect, Recite and Review (PQ4R) and Refutation Text strategies improve students' mathematical communication ability. Based on the research, it is found that the students who get the learning by using PQ4R strategy (Preview, Question, Read, Reflect, Recite and Review) and Refutation Text have increased the higher mathematical communication ability compared to the students who conventionally get the learning.

The result of hypothesis testing based on analysis of variance (ANOVA) two paths found that there is an interaction between learning strategy and mathematical reasoning ability to mathematical communication ability. According to Rubinstein-Avila \& McGraw (2008), the ability of good reasoning in the students facilitate the occurrence of information comprehension, information delivery, and information exchange from information sources. That is, there is a link between the ability of reasoning with the ability to communicate. A group of students who have high mathematical reasoning abilities and use the PQ4R 
strategy obtain higher mathematical communication ability test results than students using conventional strategies. Groups of students with low mathematical reasoning ability and using the PQ4R strategy obtained lower mathematical communication ability test results than students using conventional strategies even though there was a significant difference between them. Thus it can be seen that there is the influence of each learning strategy given both PQ4R strategy and conventional strategies related to students' mathematical reasoning abilities and give different effects on the results of mathematical communication ability.

The accuracy of the use of learning strategies following the characteristics of students and the ability of students in developing an understanding of mathematical concepts is needed. The critical role of the teacher must support this. Where the level of creativity of teachers in developing learning strategies by taking into account the characteristics of students can affect students' understanding of learning mathematics. Selection of appropriate learning strategies and potentials that students have in this case is the ability of mathematical reasoning will maximize the process of teaching and learning activities in the classroom to improve students' mathematical communication skills.

For groups of students having high mathematical reasoning abilities, it was found that there was a significant difference between the results of mathematical communication ability of the group of students using the PQ4R strategy with the outcome of mathematical communication ability of the student's group using the conventional strategy. This is indicated by the test results where for groups of students who have high mathematical reasoning ability, the average result of mathematical communication ability of a group of students using PQ4R strategy is higher than the average result of mathematical communication ability of student group using conventional strategy.

The fact can be explained that students with high mathematical reasoning ability, usually able to quickly conclude from various facts or data they get or know. This is what Rubinstein-Avila \& McGraw (2008) says that mathematical material and mathematical reasoning are two interrelated maths because mathematical reasoning and mathematical reasoning are trained through mathematical learning. That is when students have good reasoning ability in understanding the math and communicate it will be better. Students with good mathematical reasoning ability can realize reading and dig information to increase their knowledge.

There was the linkage between reading ability and mathematical communication ability since by using PQ4R strategy students with high level of mathematical reasoning ability could optimize their ability to communicate mathematically compared with those who used conventional strategy given. This may happen because after learning materials by reading (due to the PQ4R strategy), each student was given an opportunity to understand and learn first. Once students had initial knowledge of a particular material, then they knew what needs to be communicated to the teacher or peers. It was different from students given conventional strategy. High reasoning ability without the support of any information related to the material to be learned would inhibit the optimization of the ability of mathematical communication.

For groups of students who have low mathematical reasoning skills statistically, indicate that there is no difference in mathematical communication ability in students with low reasoning ability applied by PQ4R strategy and conventional strategy. Students with low mathematical reasoning ability to read and understand literacy will burden students with low mathematical reasoning skills. This is because the PQ4R strategy requires the active participation of students to build their knowledge. While the construction of knowledge is only possible when students are first equipped with good reasoning ability. 
Students with low mathematical reasoning ability feel more comfortable with conventional strategies where they only need to receive knowledge only.

The ability of mathematical communication in students with low reasoning ability applied by PQ4R strategy is similar to mathematical communication ability in students with conventional strategy. On average, however, the value of students' mathematical communication skills using the PQ4R strategy is higher than that of students using conventional strategies. The facts mentioned above can be explained that although students with low mathematical reasoning ability, fall into the category of generation Y. This generation of communication patterns is more open than previous generations. This generation is a fanatic social media user, and his life is heavily influenced by technological developments. The easy access to the internet has a significant effect on the reading and writing activities of each student who becomes higher. Utilization of information technology can be optimized by utilizing this situation where students prefer to read and then express their ideas through writing.

\section{CONCLUSION}

Based on the research that has been done, it can be concluded that the mathematical communication ability between students given PQ4R strategy in mathematics learning is higher than the students in the learning using conventional strategy and there is an interaction effect between the learning strategy and the mathematical reasoning ability to the students' mathematical communication ability.Learning with PQ4R strategy should serve as an alternative learning strategy to be implemented in the development of learning mathematics in the classroom, primarily to improve the ability of mathematical communication. Furthermore, mathematics learning with PQ4R strategies should be applicable over a more extended period, with the aim of making the learning process more optimal. Besides, students need to be familiar with reading the various sources of learning both print and electronic and write back the information obtained in the form of a brief note.

\section{ACKNOWLEDGEMENTS}

The author would like to thank Gerardus Polla and Fariani Hermin as mentors in completing the research while in Jakarta State University. The author also would like to thank the fellow teachers at STKIP Surya especially Peter John, Novi Murniati, Budi Utami, Ega Edistria, Rully C. I. Prahmana, Karina Metta and Arumella Surgandini who have provided support during the research and completion of this paper. Thanks also to Kiki Ariyanti Sugeng and Denny Riama Silaban who have always been an inspiration for the writer. In particular, the authors would like to thank Bapa Markus, Mama Rina, Kakak Krispin, Kristo, and Nando who have provided invaluable love. Lastly, thanks to my otherhalf, Kak Karlo, for his endless love dan tireless support during the process.

\section{REFERENCES}

Baig, S., \& Halai, A. (2006). Learning Mathematical Rules With Reasoning. Eurasia Journal of Mathematics, Science and Technology Education, 2(2), 15-39. Retrieved from www.ejmste.com.

Brenner, M. E. (1998). Development of Mathematical Communication in Problem Solving Groups By Language Minority Students. Bilingual Research Journal, 22(2,3,4), 103-128. 
Forrest, D.B. (2008). Communication Theory Offers Insight into Mathematics Teachers' Talk. The Mathematics Educator, 18(2), 23-32.

Foster, F.L., \& Cresap, L. (2012). Using Reasoning Tasks to Develop Skills Necessary to Learn Independently. Minot State University.

Ghasempour, Z., Kashefi, H., Bakar, M.N., \& Miri, S.A. (2012). Higher Order Thinking via Mathematical Problem Posing Tasks among Engineering Students. ASEAN Journal of Engineering Education, 1(1), 41-47.

Glynn, S.M., \& Muth, K.D. (1994). Reading and Writing to Learn Science: achieving scientific literacy. Journal of Research in Science Teaching, 31(9), 1057-1073.

Hirschfeld-Cotton, K. (2008). Mathematical communication, conceptual understanding, and students' attitudes toward mathematics.

Ho, C.H.C.Y. (2010). Intergenerational Learning (between Generation X \& Y) in Learning Families: A Narrative Inquiry. International Education Studies, 3(4), 59-72.

Kaur, B. (2012). Some" What" Strategies that Advance Reasoning and Communication in Primary Mathematics Classrooms. In Reasoning, Communication And Connections In Mathematics: Yearbook 2012, Association of Mathematics Educators (Vol. 1999, pp. 75-88).

Lagur, D.S., Makur, A.P., \& Ramda, A.H. (2018). Pengaruh Model Pembelajaran Kooperatif Tipe Numbered Head Together (NHT) terhadap Kemampuan Komunikasi Matematis. Mosharafa: Jurnal Pendidikan Matematika, 7(3), 357-368.

Larson, M.J., Whitin, D.J., \& Alexander, N.P. (2010). Young Children Use Graphs to Build Mathematical Reasoning. Dimensions of Early Childhood, 38(3), 15-22.

Lim, C. S., \& Chew, C. M. (2007). Mathematical Communication in Malaysian Bilingual Classrooms. In APEC-Tsukuba International Conference: Innovation of classroom teaching and learning through lesson study- focusing on mathematical communication (pp. 9-14). Tokyo.

Lu, Y. W. A. (2008). Linking Geometry and Algebra: A multiple-case study of UpperSecondary mathematics teacher's conceptions and practices of GeoGebra in England and Taiwan. Unpublished Master's thesis, Cambridge: University of Cambridge, UK.

Mayasari, D. (2011). Penerapan Metode Pembelajaran PQ4R (Preview, Question, Read, Reflect, Recite, Review) Dalam Meningkatkan Hasil Belajar Siswa (Penelitian Tindakan Kelas Di Smpn 3 Tangerang Selatan). Universitas Islam Negeri Syarif Hidayatullah.

Miner, R. (2005). The Importance of MathML to Communication. Notices of the AMS, 52(5), 532-538.

NCTM. (2000). Principles and standards for school mathematics. Reston, VA: NCTM.

Rasmussen, C., \& Marrongelle, K. (2006). Pedagogical Content Tools : Integrating Student Reasoning and Mathematics in Instruction. Journal for Research in Mathematics Education, 37(5), 388-420.

Rubinstein-Avila, E., \& Mcgraw, R. (n.d.). Developing mathematical reasoning among middle school immigrant students:Building on first and second language competencies. $\quad$ Retrieved from http://math.arizona.edu/ cemela/english/content/workingpapers/RubinsteinAvila\&McGraw-AERA08[1].pdf.

Sriadi, I. N. Y. (2012). The Effect Of PQ4R Strategy And Linguistic Intelligence On Reading Comprehension Of The Tenth Grade Students Post Graduate Program On Reading Comprehension Of The Tenth Grade Students. Jurnal Pendidikan Dan Pembelajaran Bahasa Indonesia, 1(2). 
Stebila, D. (2008). Improving formal reasoning in mathematics through tutorials *. Waterloo.

Suryadi, D. (2010). Pendidikan matematika. UPI. Retrieved from http://file.upi.edu/Direktori/FPMIPA/JUR._PEND._MATEMATIKA/19580201198 4031-DIDI_SURYADI/DIDI-18.pdf.

Tandililing, E. (2011). The Enhancement of Mathematical Communication and Self Regulated Learning of Senior High School Students Through PQ4R Strategy Accompanied by Refutation Text Reading. In Building the Nation Character through Humanistic Mathematics Education (pp. 978-979).

Vukovic, R. K., Roberts, S. O., \& Green Wright, L. (2013). From Parental Involvement to Children's Mathematical Performance: The Role of Mathematics Anxiety. Early Education and Development, 24(4), 446-467. https://doi.org/10.1080/10409289.2012.693430.

Wichelt, L. (2009). Communication: A Vital Skill of Mathematics. Online in http://digitalcommons.unl.edu/mathmidactionresearch/18.

\title{
Pengaruh Penerapan Strategi PQ4R dan Kemampuan Penalaran Matematis Terhadap Kemampuan Komunikasi Matematis
}

\author{
Alberta Parinters Makur * \\ Program Studi Pendidikan Matematika, STKIP Santu Paulus, Ruteng-NTT, Indonesia \\ *Penulis Korespondensi, alberta.makur@stkipsantupaulus.ac.id
}

\begin{abstract}
ABSTRAK
Penelitian ini dilakukan untuk mengetahui pengaruh penerapan strategi PQ4R dibandingkan dengan strategi konvensional terhadap kemampuan komunikasi matematis siswa ditinjau dari kemampuan penalaran matematis siswa. Metode penelitian yang digunakan adalah kuasi-eksperimen dengan populasi seluruh siswa SMAN 3 Depok. Sampel terdiri dari 76 siswa yang dipilih berdasarkan hasil tes kemampuan penalaran matematis siswa. Data diperoleh melalui soal penalaran matematis dan soal komunikasi matematis yang kemudian dianalisis dengan uji ANOVA dua jalur. Analisis dan interpretasi data menunjukkan bahwa: (1) siswa yang diajarkan dengan strategi PQ4R memiliki kemampuan komunikasi matematis lebih baik daripada siswa yang diajarkan secara konvensional; (2) ada interaksi antara strategi pembelajaran dan kemampuan penalaran matematis terhadap kemampuan komunikasi matematis; (3) siswa dengan kemampuan penalaran tinggi pada saat diterapkan strategi PQ4R memiliki kemampuan komunikasi matematis yang lebih baik dibandingkan siswa yang mendapatkan pembelajaran konvensional; (4) siswa dengan kemampuan penalaran rendah pada saat diterapkan strategi PQ4R memiliki kemampuan komunikasi matematis yang sama dengan siswa yang mendapatkan pembelajaran konvensional. Temuan mengarah pada rekomendasi bahwa kemampuan membaca dapat digunakan untuk meningkatkan kemampuan komunikasi matematis siswa dan akan memudahkan proses pembelajaran matematika di tingkat yang lebih rendah yaitu di sekolah dasar dan sekolah menengah.
\end{abstract}

Kata kunci: Kemampuan komunikasi matematis, kemampuan penalaran matematis, strategi PQ4R

Diterima 19 Oktober 2018

Direvisi 26 Oktober 2018

Disetujui 06 November 2018 